\title{
Evolution of the role of phototherapy during endodontic decontamination
}

\author{
Omid Heidar Muhammad ${ }^{1}$, Jean-Paul ROCCA ${ }^{1,2}$, Carlo Fornaini ${ }^{3}$, Etienne Medioni ${ }^{1,2}$ \\ 1: MICORALIS Laboratory (EA 7354), Faculté d'Odontologie, Université de Nice-Sophia Antipolis \\ 2: Pôle Odontologie, CHU NICE \\ 3: Dental school, Faculty of Medicine, University of Parma
}

\begin{abstract}
A microbe free root canal space before obturation leads to higher success rate and conventional chemo-mechanical debridement might not achieve this goal completely.

First trials of laser in dentistry started from surgical intervention on caries and bones of oral cavity and extended to prepare cavities and even shaping root canals. Afterward lasers were implicated soon into direct debridement of root canal space.

Anyhow failure of laser to remove debris totally from root canal space is demonstrated recently, additionally it might lead to damages to surrounding tissues or inorganic material of root canal if be used without precaution. Nowadays the theory of light assisted protocols became another start point for laser in endodontics. Laser has been introduced as an adjuvant to conventional debridement of root canals. We used Medline search engine to collect scientific publications to edit this review article in purpose of revealing the evolution of laser position from an ultimate cleaning methodology to an adjuvant to conventional root canal disinfection protocols.
\end{abstract}

Key words: Decontamination $\cdot$ Diode $\cdot$ Endodontics $\cdot$ Er:YAG $\cdot$ LASER, PDT

\section{Introduction}

The conventional endodontic treatment has high success rate. ${ }^{1)}$ Nevertheless, this treatment may fail. A great part of failures occur when treatment procedures have not reached an acceptable measure for the control and elimination of infection. ${ }^{2-4)}$ It is well-established that the mechanical debridement followed by chemical irrigation removes the bulk of the infecting microorganisms, but because the infection of root canal system is three dimensional, the residual bacteria are still detectable in an important area of the teeth just before filling the root canal. ${ }^{5-7)}$ Certain operative problems such as insufficient instrumentation, missed canals or inadequate coronal restoration might lead to periapical pathologies. ${ }^{7)}$ The complexity of root canal anatomy is another obstacle to obtain an ultimate bac-

\section{Addressee for Correspondence:}

Prof. Etienne Medioni

Address : MICORALIS Laboratory (EA 7354), Faculté

d'Odontologie, Université de Nice-Sophia Antipolis, 24,

Avenue des Diables Bleus 06357 NICE, France

E-mail :medioni@unice.fr

Tel : +33614489437 Fax : +33492001263 terial free root canal system, which makes chemomechanical debridement ineffective. ${ }^{8)}$ This complexity incorporates small accessory canals, isthmuses and dentinal tubules that do not allow direct access during the biomechanical preparation because of their location and/ or their small diameters. $\left.{ }^{9}\right)$

The success rate of endodontic treatments is higher when the canal is bacterial free at the time of obturation. ${ }^{10)}$ This was reported to reach $68-85 \%$ when so-called rigorous radiographic standards were used. The success rates were approximately 66\%, 75\%, $77 \%$, and $85 \%$ for interventions carried out by general dental practitioners, undergraduate students, graduate students, and specialists, respectively. ${ }^{11)}$ Previous studies have shown that in a microorganism free root canal environment just before filling- treatment may achieve a success rate up to $94 \%$. However, because the presence of the bacteria, this rate can be diminished to $68 \%$. ${ }^{4}$ The antimicrobial sensitivity or resistance of the polymorphous micro flora, which includes anaerobic, facultative anaerobic and aerobic bacteria, may deter-

Received date: July 7th, 2015

Accepted date: October 25th, 2015 
mine the outcome. ${ }^{9)}$

A decade after laser invention by Maiman, 12) Weichman introduced laser, for the first time, for endodontic therapy using a $10.6 \mu \mathrm{m}$ CO2 laser and then a $1064 \mathrm{~nm} \mathrm{Nd:YAG} \mathrm{laser;}{ }^{13)}$ although the results were not encouraging but the original idea brought the bravery for future studies.

After one decade of academic silence, during 1980s, Melcer, using laser in endodontics contributed lots about laser knowledge to dental sciences. ${ }^{14-17)}$ These studies were continued by other researchers like Miserandino et al. ${ }^{18)}$ Likewise, other wavelengths such as $308 \mathrm{~nm},{ }^{19)} 488 \mathrm{~nm},{ }^{20)} 1064 \mathrm{~nm}{ }^{21)}$ adopted in endodontical treatment studies.

This review throws a glance at evolution of application of different kind of lasers used with different wavelengths in the field of endodontic disinfection and aims to answer whether laser is just a "dreaming star wars" in dentistry or it is real future of the field. ${ }^{22)}$

Scientific publications concerning "Endodontics" and "Laser assisted disinfection" in PubMed database could be found from 1971. Using (Endodontics OR
Root canal) AND Laser MeSH terms, 1047 articles in English language were found until end of 2014. This search could be narrowed down for defined period of time by using publication date filter of search engine (Table 1).

A huge wave of scientific reports raised in last 5 years. In addition, this search could be restrained for articles that targeted root canal disinfection. The search should be formulated as (Endodontics OR Root Canal) AND Laser AND (Disinfection OR decontamination OR antimicrobial OR Bactericidal), which narrows down the results to 306 published articles in the selected timespan (Table 1). The antimicrobial characteristic of laser was known for many years, but in last 10 years the attention of researchers was specially brought to utilize this device to eliminate root canal bacteria (Fig. 1).

Diode lasers comes to the top of the list of the lasers when their possible ability to decontaminate root canal system is evaluated by publications indexed in PubMed. Anyhow, by a manual revision in suggested articles we found out the search results was included

Table1: Number of publications related to Endodontics and Laser and disinfection from 01.01.1971 to 31.12.2014.

\begin{tabular}{lcccccc}
\hline & Total & $1971-1981$ & $1982-1992$ & $1993-2003$ & $2004-2009$ & $2010-2014$ \\
\hline $\begin{array}{l}\text { All Articles about Endodontics and } \\
\text { Laser }\end{array}$ & 1047 & 4 & 55 & 314 & 285 & 403 \\
\hline $\begin{array}{l}\text { Articles about Endodontic disinfec- } \\
\text { tion and Laser }\end{array}$ & 306 & 0 & 4 & 44 & 89 & 174 \\
\hline
\end{tabular}

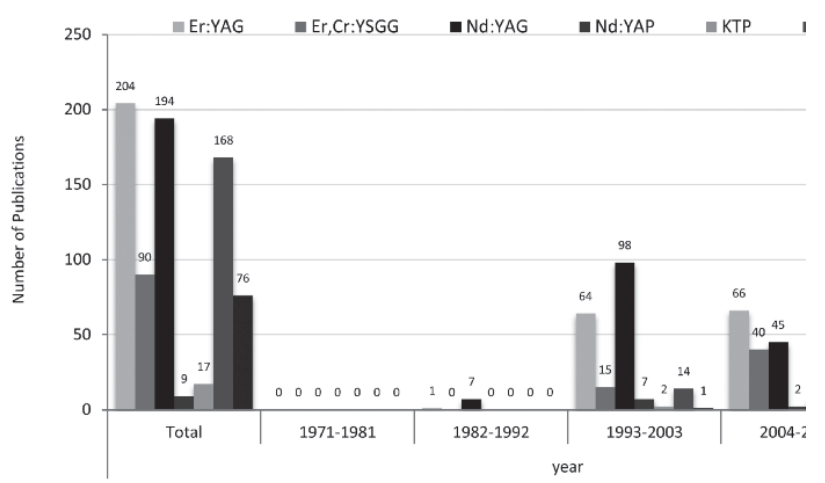

Figure 1: Distribution of scientific publications about "Endodontics" and "Laser" according to specific wavelength and PDT from 01.01.1971 to 31.12.2014.

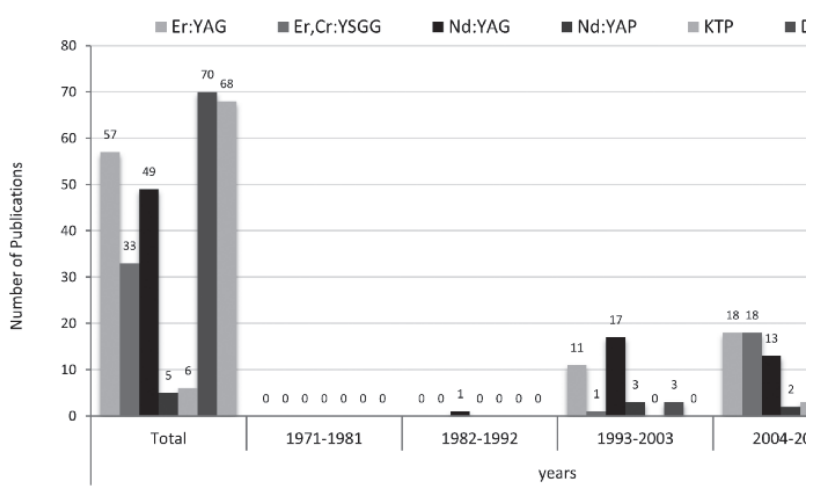

Figure 2: Distribution of scientific publications about "Endodontic Disinfection" and "Laser" according to specific wavelength and PDT from 01.01.1971 to 31.12.2014. 
many articles for photodynamic therapy in which diode laser is used as activator of photosensitizer (Fig. 2). It is important to note that the lack of homogeneity in keywords and MeSH terms used in articles may result in many unrelated articles among PubMed search results. Therefore, a manual review of results is compulsory. However, photodynamic therapy came along to be an interesting subject in terms of root canal decontamination in the last 5 years (Fig. 2).

Nd:YAG laser is still hired as machine of choice in certain endodontic protocols, however, the golden period of this laser was in 1990s and beginning of 2000s when the majority of published scientific reports in this field contributed to this wavelength. KTP laser is used anyhow to clean root canal space, but as the first application of $532 \mathrm{~nm}$ laser is treatment of vascular lesions, the capability of this device to decontaminate root canal pathogens was ignored (Fig. 2)

Erbium doped lasers are wavelengths which brought attention of researchers from their emergence till now. Er:YAG was the first laser system cleared by FDA in 1997 to treat dental decay and subsequently implicated to endodontic disinfection, thanks to its physical properties specially its affinity to $\mathrm{H} 2 \mathrm{O}$ molecules and superficially limited activity.

\section{Er:YAG}

Erbium doped lasers are machines with wide range of application; the laser beam arrives easily in most distal region of oral cavity using sapphire tips. Erbium doped yttrium aluminum garnet (Er:YAG) laser hand pieces are equipped with specially designed fiber to bring the efficiency of this laser light inside root canal space. 23,24) Er:YAG laser has been used more than any other wavelengths to study the dentin-laser interaction in the field of endodontics (Fig. 1). Topçuoğlu using inductively coupled plasma-atomic emission spectrometry (ICP-AES), demonstrated that there is no change in mineral content of dentin inside the root canal after irradiation with Er:YAG laser. ${ }^{25)}$ Application of Er:YAG laser for intra radicular disinfection, presents optimal results in microbial infection reduction from endodontic space which has been confirmed by Mehl et al. ${ }^{24)}$ These properties are dose-dependent and not selective to any bacterial species. Er:YAG with a wavelength of $2940 \mathrm{~nm}$ has highest absorption rate in water and hydroxyapatite. ${ }^{26)}$ Thus, Er:YAG is able to disrupt organized biofilms and explode the bacterial cells through a well-established mechanism of action by production of explosive vapor.

Er:YAG laser could reduce bacterial load from infected root canal ${ }^{27)}$ and it is an efficient tool for removing the smear layer. ${ }^{28)}$ This laser could clean root canal dentin from smear layer and leaves the dentinal tubules open without any harm to the inorganic structure of root canal wall and/ or surrounding periodontal tissue. Although, this result needs a direct contact of optic fiber with root canal walls; it might be a source of thermal damage if it is not controlled. 29) When root canal irradiation is coupled with a chemical antimicrobial agent like $\mathrm{NaOCl}$, it leads to a total eradication of microbes from root canal space. Such an activation with an output power of $0.3 \mathrm{~W}, 15 \mathrm{~Hz}$ for 3 period of 20 seconds could ensure an ideal result in terms of endodontic decontamination. 30) Erbium doped lasers initiate by their explosive nature of action, a cavitation effect inside irrigation solutions passing the root canal; ${ }^{31)}$ this is the principle of laser activated irrigation (LAI). Matsumoto suggested that a successful root canal treatment, especially in narrow curved root canals, might be achieved when laser activated irrigation is used for disinfection. ${ }^{32}$ Likewise, considerable reduction of output power of laser to activate irrigants is another important advantage of LAI. Nowadays, researchers are looking for getting benefits from sub-ablative energy of Er:YAG laser to activate other irrigation solutions inside the root canal. For example erbium doped laser might increase the efficiency of EDTA to remove smear layer. 33, 34) Interestingly it is reported in the literature that ultrasonic irrigation could not encourage chelating character of EDTA. ${ }^{35)}$

De Moor evidenced that LAI using an erbium doped laser with low energies $(75 \mathrm{~mJ})$ and an intermittent flushing technique ( 4 times 5 seconds) is as efficient as passive ultrasonic irrigation (PUI) to remove debris from root canal space. ${ }^{36)}$ Recent innovation in this field is PIPS or photon induced photoacoustic streaming. The mechanism of action is nearly the same than in passive ultrasonic irrigation. The laser produces acoustic waves by low energy pulses and could help irrigants to distribute inside root canal space. Furthermore, DiVito demonstrated that a stationary positioning of the fiber at the canal orifice during PIPS is enough to excite the irrigant even in apical region. 37-39) Recently, eradicative ability of PIPS against mono-species bacterial contamination was confirmed, 40) and this would be a promising technique for future application in the clinical trials.

\section{Er,Cr:YSGG}

Erbium, chromium yttrium scandium gallium garnet 
(Er,Cr:YSGG) is another member of the erbium doped lasers family. Er,Cr:YSGG with a wavelength of 2780 $\mathrm{nm}$ is better absorbed in hydroxyapatite and like Er:YAG, it has a great affinity for $\mathrm{H} 2 \mathrm{O}$ molecules. ${ }^{26}$ ) Identical to Er:YAG, Er,Cr:YSGG laser does not cause thermal damages to dentin that makes this device suitable for root canal smear layer and debris removal. ${ }^{41}$ )

Eldeniz demonstrated the bactericidal effects of Er,Cr:YSGG laser. ${ }^{42)}$ This is a time and dose dependent procedure. For instance, 60 seconds irradiation of canal with a $2 \mathrm{~W}$ power is as effective as $5 \% \mathrm{NaOCl}$ irrigation in terms of bacterial load reduction. ${ }^{43)}$ An ultimate bacterial free canal is not achievable using Er,Cr:YSGG alone, hence it brings the attention of the researchers to test its ability to enhance the effect of other cleansing agents. De Moor et al. showed the Er,Cr:YSGG laser is as effective as Er:YAG laser or passive ultrasonic irrigation to activate NaOCl. 36, 44) They demonstrated how a $2780 \mathrm{~nm}$ laser is efficient to remove debris from root canal space when the irrigant is triggered with energy of $75 \mathrm{~mJ}$ and for 20 seconds ( $4 \times 5$ seconds). Likewise, Bago Jurič showed this activation of $\mathrm{NaOCl}$ is efficient in terms of total bacterial charge reduction. ${ }^{45)}$ They demonstrated the LAI granted more bacterial free sample at the end of treatment than any other test groups. A clinical trial by Martins revealed that Er,Cr:YSGG assisted irrigation of teeth with periapical periodontitis is as effective as conventional irrigation protocols. ${ }^{46)}$ A follow up of 12 months showed a considerable reduction in peri-apical index (PAI) scores.

\section{Nd:YAG}

Nd:YAG is a near infrared laser with a wavelength of $1064 \mathrm{~nm}$ and widely used in soft tissue surgery. It is highly absorbed by hemoglobin and dark-colored tissue. ${ }^{26)}$ Antimicrobial efficacy of Nd:YAG was investigated first by Levy, Rooney and Hardee. ${ }^{47-49)}$ They all demonstrated a direct relation between dose of irradiation and the bacterial load reduction. Later on, Moshonov and Rahimi demonstrated that Nd:YAG laser could partially clean smear layer and remove bacterial colonies. ${ }^{50,51)}$ They proposed a totally cleaned root canal space from bacterial infection could be achieved when Nd:YAG laser and $\mathrm{NaOCl}$ are used in synergy.

Hence, Nd:YAG laser is a thermic laser and all bacteria present in root canal microbial biofilm are not pigmented; and Nd:YAG laser is able to inactivate bacteria by local rise of temperature leading to denaturation of enzymes and boiling the liquid presented in canal. ${ }^{52)}$ Confirming Mehl's study, ${ }^{53)}$ Meire evaluated the efficiency of $1064 \mathrm{~nm}$ laser in terms of bacterial decontamination. They used low parameters (total 80 J) to kill Enterococcus faecalis. ${ }^{54,55)}$ As the microorganism is not pigmented so the light will pass through the bacterial cytoplasm, therefore the possible mechanism of action is photo-thermic effect of laser on the environment around bacteria. However, the desired effect was not obtained because of inefficiency of laser parameter. Only by increasing the power of Nd:YAG laser beyond clinically allowed dosage, bacterial reduction was observed. Nevertheless, Pirnat demonstrated the near infra-red lasers like Nd:YAG and high power diode lasers could destroy pigmented bacteria presented in the endodontic biofilm. ${ }^{56)}$

It is well established in literature that thermal elevation produced by $\mathrm{Nd}$ :YAG laser is more than $5.5^{\circ} \mathrm{C}$ which is physiologically acceptable ${ }^{57)}$ and could cause unrecoverable response by surrounding tissue. 49,58 , 59)

In addition, Cox and Türkmen 60, 61) showed uncontrolled Nd:YAG laser irradiation may cause many undesirable effects on root canal walls. Smear layer could be formed and occlusion of some dentinal tubules linked with structural modification of dentin (recrystallization, melting and carbonization) may also be observed. Another study indicated that a direct application of Nd:YAG laser could alter structure of dentin even with lower energies $\left(25-50 \mathrm{~J} / \mathrm{cm}^{2}\right)$. $\left.{ }^{62}\right)$

\section{Nd:YAP}

Another neodymium doped laser is neodymium doped yttrium aluminum perovskite (Nd:YAP) with a wavelength of $1340 \mathrm{~nm}$. Blum was the first to propose that Nd:YAP inhibits growth of Streptococcus mitis with a frequency of $30 \mathrm{~Hz}$ and an energy of $300 \mathrm{~mJ}$. 63) Same authors in a further study suggested that the combination of subsonic irrigation and Nd:YAP laser irradiation give better results. ${ }^{64)}$ Moreover, Moshonov showed Nd:YAP laser could be implicated in root canal cleansing protocol. ${ }^{65)}$ They observed a cleaner root canal when Nd:YAP laser was involved as an adjuvant to conventional endodontic preparation methods without changing molecular composition of dentin.

Rather than a better absorption in water, Nd:YAP laser has the same photo-thermic mechanism of action when compared with Nd:YAG laser. The temperature elevation during Nd:YAP laser irradiation may become considerable and lead to damages identical to Nd:YAG laser, ${ }^{66)}$ as use of cooling water and an adapted protocol inside the root canal is required. 


\section{KTP}

The effect of potassium titanyl phosphate or KTP laser on dentin structure has been studied from its very first emergence in market. Tewfik evidenced that KTP laser is able to make changes on dentin inside the root canal. The parameters were adjusted to $1 \mathrm{~W}$ for $1 \mathrm{sec}-$ ond or $0.5 \mathrm{~W}$ for 0.5 second, because thermal elevation is about $5^{\circ} \mathrm{C}$ and could not damage periradicular tissues. ${ }^{67)}$ However, KTP laser resulted in crack formation in dentinal tubules even when using a safe range of energy. In contrast, Machida reported KTP laser is able to remove smear layer and debris from apical dentin using safe parameters $(1 \mathrm{~W} \times 6 \mathrm{~s}, 5 \mathrm{~Hz}$, repeated 5 times and at $2 \mathrm{~W} \times 3 \mathrm{~s}, 5 \mathrm{~Hz}$, repeated 5 times). 68) This clarified that power and working time influence the outcome of laser treatment on root canal walls. In addition, it is important to consider resting time to avoid any cumulative thermal damage. ${ }^{69)}$

KTP is capable to reduce bacterial load, but its efficiency is inferior to the results from $\mathrm{NaOCl}$ alone. 70) Since we know that total eradication of bacteria from root canal space is not possible, the ideal protocol seems to be the conjunction of both chemomechanical debridement and laser irradiation. ${ }^{71}$ )

\section{Diodes}

Another group of lasers are semiconductor or diode lasers. Diodes rapidly found their way into laser-assisted dentistry thanks to their small size, ease of use and affordable price. Diode lasers with a big range of different wavelengths from visible to infrared contributed a lot to the field of endodontics especially endodontic disinfection.

For the first time in 1997, Moritz examined an 810 $\mathrm{nm}$ diode laser ability to kill root canal bacteria in in vitro and in vivo studies. ${ }^{72,73)}$ Furthermore it was verified that this wavelength is able to decontaminate deep layers of radicular dentin which is an important point to overcome the 3-dimensional aspect of root canal space. ${ }^{74}$ ) It could be explained by the phenomenon that diode laser is not absorbed in water or inorganic material which leads to scattering of laser beam into deeper layer of dentin. ${ }^{75)}$ Same results were obtained by $830 \mathrm{~nm},{ }^{76)} 940 \mathrm{~nm}^{77)}$ and $980 \mathrm{~nm}^{78}$ ) diode lasers. These findings demonstrated different wavelengths of diode laser are all effective in terms of reduction of bacterial load.

da Costa Ribeiro showed photo-thermic damage of diode laser is negligible when reasonable parameters are used. ${ }^{79)}$ They showed thermal elevation caused by this laser is up to $8.6^{\circ} \mathrm{C}$ in continuous mode and between 1.2 to $3.3^{\circ} \mathrm{C}$ in pulsed mode which is crucial to prevent any harm to periodontal tissue. However, still this little thermal change could result in closure of dentinal tubules. To prevent any cumulative thermal effect, it is mandatory to consider recovery time during diode laser irradiation interval. Respecting this rule, diode laser could be counted as a safe laser with different power level ${ }^{80}$ ) which could raise up to 3 $\mathrm{W}$ if it has been used in pulsed mode. ${ }^{81)}$ Stationary contact of fiber tip with dentin leads to overheating and melting the dentin and further thermal damage to surrounding tissues. For this reason constant moving of fiber during irradiation is fundamental. ${ }^{80-82)}$

The morphological changes caused by diode lasers in root canal dentin are power dependent. Diode lasers removes smear layer at $1.5 \mathrm{~W}$, but increasing power leads to extreme changes in dentin like melting of surface dentin. ${ }^{83-85)}$ Nevertheless, despite any morphological alteration initiated, diode lasers have no adverse effect on structural characteristic of mineral matrix of root canal. ${ }^{85)}$ Smear layer elimination could be achieved using diode laser in conjunction with some irrigation solutions. However, the kind of irrigation solutions determine the outcome of treatment. ${ }^{84)}$ For example, synergy of diode laser and $\mathrm{NaOCl}$ produces smear layer, but combination of diode laser and EDTA results in smear layer elimination. ${ }^{86)}$ In another study, activation of EDTAC ${ }^{\circledR}$ by a $940 \mathrm{~nm}$ diode laser seems to be an ideal protocol to remove smear layer, but irradiation of hydrogen peroxide with same parameters develops no significant effects on smear layer. 87)

Diode lasers might contribute to activation of irrigation solutions thanks to their high frequency that reaches to $20-50 \mathrm{KHz}$. This property of diode laser could promote cavitation effect inside root canal irrigants and subsequent better debridement. ${ }^{88)}$ Neelakantan demonstrated the diode laser is as efficient as Er:YAG laser to activate irrigants in the root canal and disturb microbial biofilm. ${ }^{34)}$ However, in another study it has been indicated that there are some differences in quality of explosive vapor initiated by diode and Er:YAG lasers. The peak of cavitation and bubbles formation with diode laser happens with a delay after irradiation starts. Due to slower fluid movement during irradiation by diode laser, the possibility of irrigants extrusion beyond dental apex is less than that of Er:YAG laser. ${ }^{89)}$ However, there is a proportional relationship between irrigant volume in root canal spaces and the power needed to activate it. The form of the fiber may enhance the outcome. George introduced a modified 
light delivery fiber called honeycomb tip to enhance the agitation and cavitation properties of diode laser. Using this fiber, diode laser makes more bubbles toward root canal walls and less in apical direction. As well the time needed to achieve peak cavitation is inferior to that of plain fiber. However, the factor of power is playing an important role. The cavitation occurs always in a power level more than $2 \mathrm{~W} .{ }^{89)}$

\section{PDT}

Photodynamic therapy (PDT) is a medical treatment which utilizes light to activate an agent called photosensitizer in presence of oxygen. Many Photosensitizers and different from chemical photosensitizing agents like toluidine blue, 90, 91) methylene blue 92,93$)$ to natural photosensitizers like curcumin 94) have been examined. The outcome of PDT in different protocol with different activating lights has been tested. However, using different types of laser does not improve the outshot of PDT. 95)

As a pioneer, Wilson mentioned bactericidal effects of PDT in dental diseases. 96, 97) Afterward, the potential role of PDT in total eradication of root canal infection was outlined in many researches. 98-101) The number of scientific publication on this topic is increasing in recent years (Fig. 2). A high degree of safety of PDT could be a reason for such significant progress. ${ }^{102)}$

The results of studies are controversial. It is demonstrated conventional photo-activated disinfection (PAD) could not disrupt polybacterial plaque but it might reduce a mono-species biofilm made of Enterococcus faecalis. ${ }^{103)}$ Anyhow, Yao suggested that PDT is more effective on planktonic form of bacteria than their biofilm state inside root canals. ${ }^{104)}$ Thus, the conventional disruption of intracanal biofilm before PDT is critical for success of treatment. ${ }^{92)}$ Clinical trials of Jurič very well demonstrated application of PDT after conventional debridement of root canal space to obtain a bacterial free canal. ${ }^{105)}$

Concerning biofilm - PDT interaction, it is evidenced that different PDT protocols could not be effective without pretreatment of biofilm with conventional decontaminating agents like NaOCl. 106, 107) Anyhow, promising results are reported especially when more incubation time with Photosensitizer and longer irradiation is applied. 99,108$)$ An in vitro study by Komine and Tsujimoto exhibited that the highest amount of singlet oxygen generated through photodynamic therapy could be achieved after longest time of irradiation. 93) Regarding working time, these conditions seem to be difficult to apply in daily clinical procedures particularly when treating multi rooted teeth. To overcome this problem, PDT in 2 visits could be beneficial. 109, 110) However, there are controversies about irradiation time; interestingly, Yildirim reported that there is no difference between 1 minute and 4 minutes irradiation of photosensitizers. ${ }^{111)}$

The quality of activating light may also influence the outcome. For example, emitters or light diffuser optic fiber could scatter unidirectional light of diode laser to ensure maximum reach even in the most distal zones of root canal. $\left.{ }^{99}, 112\right)$ Light emitting diodes (LED) showed to be promising in terms of activating the photosensitizers. ${ }^{113)}$ LED light travels easily in all direction with no need to move the optic fiber. This may lead to better results in terms of bacterial load reduction rather than PDT utilizing a unidirectional diode laser (Fig. 3). 107)

Recently, another study by Sabino demonstrated different effect of a same light source on a bioluminescent species of Candida albicans. ${ }^{114)}$ When microorganisms are irradiated with laser using a light diffuser fiber, the reduction in bacterial load is 100 times more than using a normal optic fiber.

\section{$\mathrm{CO} 2$}

Zakariasen was the first to propose an exposure of 1 second to a $10 \mathrm{~W}$ CO2 laser beam leads to bacterial death, 115) but later on its effects on root canal dentin were studied. ${ }^{116)}$ Takeda demonstrated that by placing a conical tip inside the root canal and using $3 \mathrm{~W}, \mathrm{CO} 2$ laser could remove smear layer partially. ${ }^{28)}$ However, in some regions some undesired effects like burning, melting, recrystallization and glazing of dentine were observed too and confirmed by other studies. ${ }^{61}$ ) Likewise, an in vitro studies proposed that irradiation of root canal space by $\mathrm{CO} 2$ laser using a hollow fiber at $30 \mathrm{~J}$ energy in either pulsed or super-pulsed mode may lead to damage to tissues beyond the apex. ${ }^{117)}$ Additionally, CO2 laser light could not be transferred via an optic fiber ${ }^{118)}$ and trials to deliver the energy of a defocused laser beam inside root canal space also failed. ${ }^{119)}$ Regarding difficulties in irradiation of $\mathrm{CO}_{2}$ laser and subsequent undesirable effects, logically and at the present time, there is no more interest to deploy such wavelength in terms of root canal disinfection.

\section{Conclusion}

If we look to the milestone of laser in endodontics, the beginning of the way is marked with issues regarding 
energy leading to undesirable effects on dentin and periradicular environment. Thanks to constant evolution of laser technology and progressive scientific experiments, nowadays it is well documented that lower energies could provoke the intended objectives.

Laser assisted endodontic decontamination in conjugation with conventional chemical solutions activated by laser should be favored over direct use of laser to remove bacterial biofilm from root canal space. Both erbium doped lasers through explosive vapor and diode lasers with short pulses and high frequencies could produce cavitation effect inside irrigation solutions and result in a 3-dimensionally clean root canal walls, free from smear layer and debris even in apical region. This does not need high energies and could prevent unwanted thermal and physical side effects to root canal dentin or other surrounding tissues.

It is known that common root canal irrigation solutions could absorb light in different wavelengths from $513 \mathrm{~nm}$ for chlorhexidine (CHX) to $2200 \mathrm{~nm}$ for citric acid. In addition, different irrigants have high absorption rate for wavelengths higher than $2500 \mathrm{~nm}$. These optical properties make all tested irrigants qualified for LAI. 120) The important point is to match the right irrigant with available wavelength or vice versa.

Mechanism of photodynamic therapy is quite different from physical interaction of LAI which is based on wave production in irrigants or direct root canal decontamination by near infra-red lasers which work by thermal elevation. PDT is a pure chemical reaction and it could not clean totally the root canal space from microbial biofilm, alone. It should be kept in mind that photodynamic therapy is an adjuvant and not a substitute to conventional chemo-mechanical debridement. Thus, there is no resistance or selectivity toward PDT, it might be helpful removing bacteria from root canal space especially microbial flora of chronic endodontic disease or/ and those resistant to antibiotics.
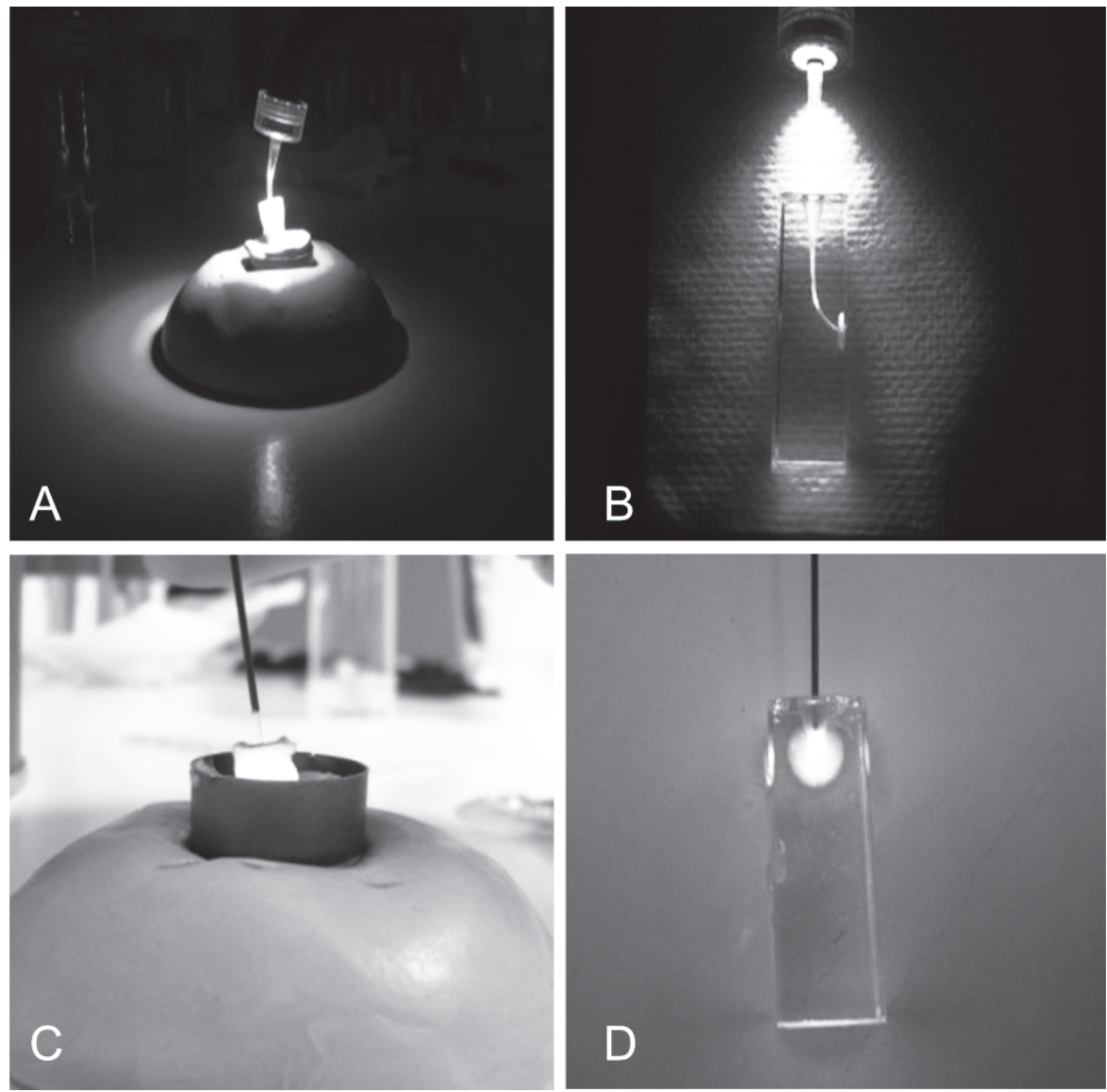

Figure 3: Quality of light may be effective on the outcome of PDT. A, B: Non-collimated, intense LED light could travel in all direction and does not need to be moved to excite photosensitive agent. C, D: Collimated $650 \mathrm{~nm}$ diode laser light needs to be moved through the canal to activate photosensitizer. ${ }^{107)}$ 


\section{References}

1: Tavares PB, Bonte E, Boukpessi T, Siqueira JF, Jr., Lasfargues JJ. Prevalence of apical periodontitis in root canal-treated teeth from an urban French population: influence of the quality of root canal fillings and coronal restorations. J Endod 2009; 35(6): 810-813.

2: Nair PN. Pathogenesis of apical periodontitis and the causes of endodontic failures. Crit Rev Oral Biol Med. 2004; 15(6): 348-381.

3: Siqueira JF, Jr. Aetiology of root canal treatment failure: why well-treated teeth can fail. Int Endod J 2001; 34(1): 1-10.

4: Sjogren U, Figdor D, Persson S, Sundqvist G. Influence of infection at the time of root filling on the outcome of endodontic treatment of teeth with apical periodontitis. Int Endod J 1997; 30(5): 297-306.

5: Bystrom A, Sundqvist G. Bacteriologic evaluation of the effect of 0.5 percent sodium hypochlorite in endodontic therapy. Oral Surg Oral Med Oral Pathol 1983; 55(3): 307-312.

6: Singla M, Aggarwal V, Logani A, Shah N. Comparative evaluation of rotary ProTaper, Profile, and conventional stepback technique on reduction in Enterococcus faecalis colony-forming units and vertical root fracture resistance of root canals. Oral Surg Oral Med Oral Pathol Oral Radiol Endod 2010; 109(3): e105-110.

7: Sundqvist G, Figdor D, Persson S, Sjogren U. Microbiologic analysis of teeth with failed endodontic treatment and the outcome of conservative re-treatment. Oral Surg Oral Med Oral Pathol Oral Radiol Endod 1998; 85(1): 86-93.

8: Siqueira JF, Jr., Araujo MC, Garcia PF, Fraga RC, Dantas CJ. Histological evaluation of the effectiveness of five instrumentation techniques for cleaning the apical third of root canals. J Endod 1997; 23(8): 499-502.

9: Garcez AS, Ribeiro MS, Tegos GP, Nunez SC, Jorge AO, Hamblin MR. Antimicrobial photodynamic therapy combined with conventional endodontic treatment to eliminate root canal biofilm infection. Lasers Surg Med 2007; 39(1): 59-66.

10: Siren EK, Haapasalo MP, Waltimo TM, Orstavik D. In vitro antibacterial effect of calcium hydroxide combined with chlorhexidine or iodine potassium iodide on Enterococcus faecalis. Eur J Oral Sci 2004; 112(4): 326-331.

11: Ng YL, Mann V, Rahbaran S, Lewsey J, Gulabivala $\mathrm{K}$. Outcome of primary root canal treatment: systematic review of the literature - part 1. Effects of study characteristics on probability of success. Int Endod J 2007; 40(12): 921-939.

12: Maiman T. Stimulated optical radiation in ruby. Nature. 1960; 187: 493-494.

13: Weichman JA, Johnson FM, Nitta LK. Laser use in endodontics. II. Oral Surg, Oral Med, Oral Pathol 1972; 34(5): 828-830.

14: Melcer F, Melcer J. [Results of short and medium term use of $\mathrm{CO}_{2}$ lasers in dentistry]. L' Information dentaire. 1982;6 4(22): 2147-2151.

15: Melcer J, Melcer F, Hasson R, Merard R, Gautier J. [The contribution of the $\mathrm{CO} 2$ laser in the treatment of periapical foci]. Revue d'odonto-stomatologie. 1982; 11(5): 351-355.

16: Wolcott J, Ishley D, Kennedy W, Johnson S, Minnich S, Meyers J. A 5 yr clinical investigation of second mesiobuccal canals in endodontically treated and retreated maxillary molars. J Endod 2005; 31(4): 262-264.

17: Olivi G, Genovese MD. Laser restorative dentistry in children and adolescents. Eur Arch Paediatr Dent. 2011; 12(2): 68-78.

18: Miserendino LJ. The laser apicoectomy: endodontic application of the $\mathrm{CO} 2$ laser for periapical surgery. Oral Surg Oral Med Oral Pathol 1988; 66(5): 615-619.

19: Pini R, Salimbeni R, Vannini M, Barone R, Clauser C. Laser dentistry: a new application of excimer laser in root canal therapy. Lasers Surg Med 1989; 9(4): 352-357.

20: Potts TV, Petrou A. Argon laser initiated resin photopolymerization for the filling of root canals in human teeth. Lasers Surg Med 1991; 11(3): 257-262.

21: Sumitomo M, Furuya H. Biomedical engineering for the conservation of teeth--the use of a Nd-YAG laser for a treatment of apical focus. Front Med Biol Eng 1989; 1(2): 89-97.

22: Zakariasen KL, Dederich DN, Tulip J. Lasers in dentistry. "Star wars". Dreaming or a future reality? J Can Dent Assoc 1988; 54(1): 27-30.

23: Guidotti R, Merigo E, Fornaini C, Rocca J-P, Medioni E, Vescovi P. Er:YAG 2,940-nm laser fiber in endodontic treatment: a help in removing smear layer. Lasers Med Sci 2014; 29(1): 69-75.

24: Mehl A, Folwaczny M, Haffner C, Hickel R. Bactericidal effects of 2.94 microns Er:YAG-laser radiation in dental root canals. J Endod 1999; 25(7): 490-493.

25: Topçuoğlu H, Köseoğlu M. Effect of Er:YAG and Nd:YAG lasers on the mineral content of root canal dentin. Lasers Med Sci 2015; 30(2): 809-813. 
26: Steiner R. Laser-Tissue Interactions. In: Raulin C, Karsai S, editors. Laser and IPL technology in dermatology and aesthetic medicine: Springer Berlin Heidelberg; 2011. p. 23-36.

27: Yasuda Y, Kawamorita T, Yamaguchi H, Saito T. Bactericidal effect of Nd:YAG and Er:YAG lasers in experimentally infected curved root canals. Photomed Laser Surg 2010; 28 Suppl 2: S75-78.

28: Takeda FH, Harashima T, Kimura Y, Matsumoto K. A comparative study of the removal of smear layer by three endodontic irrigants and two types of laser. Int Endod J. 1999; 32(1): 32-39.

29: Takeda FH, Harashima T, Kimura Y, Matsumoto K. Efficacy of Er:YAG laser irradiation in removing debris and smear layer on root canal walls. J Endod 1998; 24(8): 548-551.

30: Cheng X, Guan S, Lu H, Zhao C, Chen X, Li N, et al. Evaluation of the bactericidal effect of Nd:YAG, Er:YAG, Er,Cr:YSGG laser radiation, and antimicrobial photodynamic therapy (aPDT) in experimentally infected root canals. Lasers Surg Med 2012; 44(10): 824-831.

31: Blanken J, De Moor RJG, Meire M, Verdaasdonk R. Laser induced explosive vapor and cavitation resulting in effective irrigation of the root canal. Part 1: A visualization study. Lasers Surg Med 2009; 41(7): 514-519.

32: Matsumoto H, Yoshimine Y, Akamine A. Visualization of irrigant flow and cavitation induced by Er:YAG laser within a root canal model. J Endod 2011; 37(6): 839-843.

33: George R, Meyers IA, Walsh LJ. Laser activation of endodontic irrigants with improved conical laser fiber tips for removing smear layer in the apical third of the root canal. J Endod 2008; 34(12): 1524-1527.

34: Neelakantan P, Cheng CQ, Mohanraj R, Sriraman P, Subbarao C, Sharma S. Antibiofilm activity of three irrigation protocols activated by ultrasonic, diode laser or Er:YAG laser in vitro. Int Endod J 2015; 48(6): 602-610.

35: Abbott PV, Heijkoop PS, Cardaci SC, Hume WR, Heithersay GS. An SEM study of the effects of different irrigation sequences and ultrasonics. Int Endod J 1991; 24(6): 308-316.

36: De Moor RJG, Meire M, Goharkhay K, Moritz A, Vanobbergen J. Efficacy of ultrasonic versus laseractivated irrigation to remove artificially placed dentin debris plugs. J Endod 2010; 36(9): 1580-1583.

37: DiVito E, Peters OA, Olivi G. Effectiveness of the erbium:YAG laser and new design radial and stripped tips in removing the smear layer after root canal instrumentation. Lasers Med Sci 2012; 27(2):
273-280.

38: DiVito E, Lloyd A. ER:YAG laser for 3-dimensional debridement of canal systems: use of photoninduced photoacoustic streaming. Dent Today 2012; 31(11): 122, 124-127.

39: Al Shahrani M, DiVito E, Hughes CV, Nathanson D, Huang GT. Enhanced removal of Enterococcus faecalis biofilms in the root canal using sodium hypochlorite plus photon-induced photoacoustic streaming: an in vitro study. Photomed Laser Surg 2014; 32(5): 260-266.

40: Olivi G, DiVito E, Peters O, Kaitsas V, Angiero F, Signore A, et al. Disinfection efficacy of photoninduced photoacoustic streaming on root canals infected with Enterococcus faecalis: an ex vivo study. J Am Dent Assoc. 2014; 145(8): 843-848.

41: Yamazaki R, Goya C, Yu DG, Kimura Y, Matsumoto K. Effects of erbium,chromium:YSGG laser irradiation on root canal walls: a scanning electron microscopic and thermographic study. J Endod 2001; 27(1): 9-12.

42: Eldeniz AU, Ozer F, Hadimli HH, Erganis O. Bactericidal efficacy of Er,Cr:YSGG laser irradiation against Enterococcus faecalis compared with $\mathrm{NaOCl}$ irrigation: an ex vivo pilot study. Int Endod J 2007; 40(2): 112-119.

43: Arnabat J, Escribano C, Fenosa A, Vinuesa T, GayEscoda C, Berini L, et al. Bactericidal activity of erbium, chromium:yttrium-scandium-gallium-garnet laser in root canals. Lasers Med Sci 2010; 25(6): 805-810.

44: De Moor RJG, Blanken J, Meire M, Verdaasdonk R. Laser induced explosive vapor and cavitation resulting in effective irrigation of the root canal. Part 2: Evaluation of the efficacy. Lasers Surg Med 2009; 41(7): 520-523.

45: Bago Juric I, Plecko V, Anic I. Antimicrobial efficacy of Er,Cr:YSGG laser-activated irrigation compared with passive ultrasonic irrigation and RinsEndo((R)) against intracanal Enterococcus faecalis. Photomed Laser Surg 2014; 32(11): 600-605.

46: Martins MR, Carvalho MF, Pina-Vaz I, Capelas JA, Martins MA, Gutknecht N. Outcome of Er,Cr:YSGG laser-assisted treatment of teeth with apical periodontitis: A blind randomized clinical trial. Photomed Laser Surg 2013; 32(1): 3-9.

47: Levy G. Cleaning and shaping the root canal with a Nd:YAG laser beam: a comparative study. J Endod 1992; 18(3): 123-127.

48: Rooney J, Midda M, Leeming J. A laboratory investigation of the bactericidal effect of a NdYAG laser. Br Dent J 1994; 176(2): 61-64. 
49: Hardee MW, Miserendino LJ, Kos W, Walia H. Evaluation of the antibacterial effects of intracanal Nd: YAG laser irradiation. J Endod 1994; 20(8): 377-380.

50: Moshonov J, Ørstavik D, Yamauchi S, Pettiette M, Trope M. Nd:YAG laser irradiation in root canal disinfection. Dent Traumatol 1995; 11(5): 220-224.

51: Rahimi S, Shahi S, Gholizadeh S, Shakouie S, Rikhtegaran S, Soroush Barhaghi $\mathrm{MH}$, et al. Bactericidal effects of Nd:YAG laser irradiation and sodium hypochlorite solution on Enterococcus Faecalis biofilm. Photomed Laser Surg 2012; 30(11): 637-641.

52: Pirnat S, Lukac M, Ihan A. Thermal tolerance of $E$. faecalis to pulsed heating in the millisecond range. Lasers Med Sci 2011; 26(2): 229-237.

53: Mehl A, Kremers L, Salzmann K, Hickel R. 3D volume-ablation rate and thermal side effects with the Er:YAG and Nd:YAG laser. Dent Mater 1997; 13(4): 246-251.

54: Meire MA, De Prijck K, Coenye T, Nelis HJ, De Moor RJ. Effectiveness of different laser systems to kill Enterococcus faecalis in aqueous suspension and in an infected tooth model. Int Endod J 2009; 42(4): 351-359.

55. Meire MA, Coenye T, Nelis HJ, De Moor RJG. Evaluation of Nd:YAG and Er:YAG irradiation, antibacterial photodynamic therapy and sodium hypochlorite treatment on Enterococcus faecalis biofilms. Int Endod J 2012; 45(5): 482-491.

56: Pirnat S, Lukac M, Ihan A. Study of the direct bactericidal effect of Nd:YAG and diode laser parameters used in endodontics on pigmented and nonpigmented bacteria. Lasers Med Sci 2011; 26(6): 755-761.

57: Zach L, Cohen G. Pulp response to externally applied heat. Oral Surg Oral Med Oral Pathol 1965; 19: 515-530

58: Amyra T, Walsh LT, Walsh LJ. An assessment of techniques for dehydrating root canals using infrared laser radiation. Aust Endod J 2000; 26(2): 78-80.

59: Folwaczny M, Mehl A, Jordan C, Hickel R. Antibacterial effects of pulsed Nd:YAG laser radiation at different energy settings in root canals. J Endod 2002; 28(1): 24-29.

60: Cox CJ, Pearson GJ, Palmer G. Preliminary in vitro investigation of the effects of pulsed Nd:YAG laser radiation on enamel and dentine. Biomaterials 1994; 15(14): 1145-1151.

61: Türkmen C, Günday M, Karaçorlu M, Başaran B. Effect of $\mathrm{CO} 2, \mathrm{Nd}: \mathrm{YAG}$, and ArF excimer lasers on dentin morphology and pulp chamber temperature: An in vitro study. J Endod 2000; 26(11): 644-648.

62: Tani Y, Kawada H. Effects of laser irradiation on dentin. I. Effect on smear layer. Dent Mater J 1987; 6(2): 127-134.

63: Blum JY, Michailesco P, Abadie MJ. An evaluation of the bactericidal effect of the Nd:YAP laser. J Endod 1997; 23(9): 583-585.

64: Blum JY, Abadie MJ. Study of the Nd:YAP laser. Effect on canal cleanliness. J Endod 1997; 23(11): 669-675.

65: Moshonov J, Peretz B, Brown T, Rotstein I. Cleaning of the root canal using Nd:YAP laser and its effect on the mineral content of the dentin. J Clin Laser Med Surg 2004; 22(2): 87-89.

66: Armengol V, Jean A, Marion D. Temperature rise during Er:YAG and Nd:YAP laser ablation of dentin. J Endod 2000; 26(3): 138-141.

67: Tewfik HM, Pashley DH, Horner JA, Sharawy MM. Structural and functional changes in root dentin following exposure to KTP/532 laser. J Endod 1993; 19(10): 492-497.

68: Machida T, Wilder-Smith P, Arrastia AM, Liaw LHL, Berns MW. Root canal preparation using the second harmonic KTP:YAG laser: A thermographic and scanning electron microscopic study. J Endod 1995; 21(2): 88-91.

69: Nammour S, Kowaly K, Powell GL, Van Reck J, Rocca JP. External temperature during KTPNd:YAG laser irradiation in root canals: an in vitro study. Lasers Med Sci 2004; 19(1): 27-32.

70: Kuştarci A, Sümer Z, Altunbaş D, Koşum S. Bactericidal effect of KTP laser irradiation against Enterococcus faecalis compared with gaseous ozone: an ex vivo study. Oral Surg Oral Med Oral Pathol Oral Radiol Endod 2009; 107(5):e73-e79.

71: Romeo U, Palaia G, Nardo A, Tenore G, Telesca V, Kornblit R, et al. Effectiveness of KTP laser versus $980 \mathrm{~nm}$ diode laser to kill Enterococcus faecalis in biofilms developed in experimentally infected root canals. Aust Endod J 2015; 41(1) 17-23.

72: Moritz A, Gutknecht N, Schoop U, Goharkhay K, Doertbudak O, Sperr W. Irradiation of infected root canals with a diode laser in vivo: Results of microbiological examinations. Lasers Surg Med 1997; 21(3): 221-226.

73: Moritz A, Gutknecht N, Goharkhay K, Schoop U, Wernisch J, Sperr W. In vitro irradiation of infected root canals with a diode laser: results of microbiologic, infrared spectrometric, and stain penetration examinations. Quintessence Int 1997; 28(3): 205-209.

74: Gutknecht N, van Gogswaardt D, Conrads G, Apel 
C, Schubert C, Lampert F. Diode laser radiation and its bactericidal effect in root canal wall dentin. J Clin Laser Med Surg 2000; 18(2): 57-60.

75: Esteves-Oliveira M, de Guglielmi CA, Ramalho KM, Arana-Chavez VE, de Eduardo CP. Comparison of dentin root canal permeability and morphology after irradiation with Nd:YAG, Er:YAG, and diode lasers. Lasers Med Sci 2010; 25(5):755-760.

76: de Souza EB, Cai S, Simionato MRL, Lage-Marques JL. High-power diode laser in the disinfection in depth of the root canal dentin. Oral Surg Oral Med Oral Pathol Oral Radiol Endod 2008; 106(1): e68-e72.

77: Beer F, Buchmair A, Wernisch J, Georgopoulos A, Moritz A. Comparison of two diode lasers on bactericidity in root canals--an in vitro study. Lasers Med Sci 2012; 27(2): 361-364.

78: Gutknecht N, Franzen R, Schippers M, Lampert F. Bactericidal effect of a 980-nm diode laser in the root canal wall dentin of bovine teeth. J Clin laser Med Surg 2004; 22(1): 9-13.

79: da Costa Ribeiro A, Nogueira GE, Antoniazzi JH, Moritz A, Zezell DM. Effects of diode laser (810 $\mathrm{nm}$ ) irradiation on root canal walls: thermographic and morphological studies. J Endod 2007; 33(3): 252-255.

80: Gutknecht N, Franzen R, Meister J, Vanweersch L, Mir M. Temperature evolution on human teeth root surface after diode laser assisted endodontic treatment. Lasers Med Sci 2005; 20(2): 99-103.

81: Alfredo E, Marchesan MA, Sousa-Neto MD, Brugnera-Júnior A, Silva-Sousa YTC. Temperature variation at the external root surface during 980$\mathrm{nm}$ diode laser irradiation in the root canal. J Dent 2008; 36(7): 529-534.

82: Kreisler M, Kohnen W, Beck M, Al Haj H, Christoffers AB, Götz H, et al. Efficacy of $\mathrm{NaOCl} / \mathrm{H}_{2} \mathrm{O} 2$ irrigation and GaAlAs laser in decontamination of root canals in vitro. Lasers Surg Med 2003; 32(3): 189-196.

83: Marchesan MA, Brugnera-Junior A, Souza-Gabriel AE, Correa-Silva SR, Sousa-Neto MD. Ultrastructural analysis of root canal dentine irradiated with 980$\mathrm{nm}$ diode laser energy at different parameters. Photomed Laser Surg 2008; 26(3): 235-240.

84: Marchesan MA, Brugnera-Junior A, Ozorio JE, Pécora JD, Sousa-Neto MD. Effect of 980-nanometer diode laser on root canal permeability after dentin treatment with different chemical solutions. J Endod 2008; 34(6): 721-724.

85: Faria M, Sousa-Neto M, Souza-Gabriel A, Alfredo E, Romeo U, Silva-Sousa Y. Effects of 980-nm diode laser on the ultrastructure and fracture resistance of dentine. Lasers Med Sci 2013; 28(1): 275-280.

86: Alfredo E, Souza-Gabriel AE, Silva SR, Sousa-Neto MD, Brugnera-Junior A, Silva-Sousa YT. Morphological alterations of radicular dentine pretreated with different irrigating solutions and irradiated with 980-nm diode laser. Microsc Res Tech 2009; 72(1): 22-27.

87: Lagemann M, George R, Chai L, Walsh LJ. Activation of ethylenediaminetetraacetic acid by a $940 \mathrm{~nm}$ diode laser for enhanced removal of smear layer. Aust Endod J 2014; 40(2): 72-75.

88: Hmud R, Kahler WA, George R, Walsh LJ. Cavitational effects in aqueous endodontic irrigants generated by near-infrared lasers. J Endod 2010; 36(2): $275-278$.

89: George R, Chan K, Walsh LJ. Laser-induced agitation and cavitation from proprietary honeycomb tips for endodontic applications. Lasers Med Sci 2015; 30(4): 1203-1208.

90: Fonseca MB, Júnior POT, Pallota RC, Filho HF, Denardin OVP, Rapoport A, et al. Photodynamic therapy for root canals infected with Enterococcus faecalis. Photomed Laser Surg 2008; 26(3): 209-213.

91: Bouillaguet S, Wataha JC, Zapata O, Campo M, Lange N, Schrenzel J. Production of reactive oxygen species from photosensitizers activated with visible light sources available in dental offices. Photomed Laser Surg 2009; 28(4): 519-525.

92: Ng R, Singh F, Papamanou DA, Song X, Patel C, Holewa C, et al. Endodontic photodynamic therapy ex vivo. J Endod 2011; 37(2): 217-222.

93: Komine C, Tsujimoto Y. A small amount of singlet oxygen generated via excited methylene blue by photodynamic therapy induces the sterilization of Enterococcus faecalis. J Endod 2013; 39(3): 411-414.

94: Paschoal MA, Tonon CC, Spolidório DMP, Bagnato VS, Giusti JSM, Santos-Pinto L. Photodynamic potential of curcumin and blue LED against Streptococcus mutans in a planktonic culture. Photodiagnosis Photodyn Ther 2013; 10(3): 313-319.

95: Kübler AC. Photodynamic therapy. Med Laser Appli 2005; 20(1): 37-45.

96: Wilson M, Dobson J, Harvey W. Sensitization of oral bacteria to killing by low-power laser radiation. Curr Microbiol 1992; 25(2): 77-81.

97: Wilson M. Photolysis of oral bacteria and its potential use in the treatment of caries and periodontal disease. J Appl Bacteriol 1993; 75(4): 299-306.

98: Silva Garcez A, Núñez SC, Lage-Marques JL, Jorge AOC, Ribeiro MS. Efficiency of $\mathrm{NaOCl}$ and laserassisted photosensitization on the reduction of Enterococcus faecalis in vitro. Oral Surg Oral Med 
Oral Pathol Oral Radiol Endod 2006;102(4): e93-e98.

99: Soukos NS, Chen PS-Y, Morris JT, Ruggiero K, Abernethy AD, Som S, et al. Photodynamic therapy for endodontic disinfection. J Endod 2006; 32(10): 979-984.

100:Foschi F, Fontana CR, Ruggiero K, Riahi R, Vera A, Doukas AG, et al. Photodynamic inactivation of Enterococcus faecalis in dental root canals in vitro. Lasers Surg Med 2007; 39(10): 782-787.

101:Fimple JL, Fontana CR, Foschi F, Ruggiero K, Song $\mathrm{X}$, Pagonis TC, et al. Photodynamic treatment of endodontic polymicrobial infection in vitro. J Endod 2008; 34(6): 728-734.

102:Xu Y, Young MJ, Battaglino RA, Morse LR, Fontana CR, Pagonis TC, et al. Endodontic antimicrobial photodynamic therapy: safety assessment in mammalian cell cultures. J Endod 2009; 35(11): $1567-$ 1572.

103:Stojicic S, Amorim H, Shen Y, Haapasalo M. Ex vivo killing of Enterococcus faecalis and mixed plaque bacteria in planktonic and biofilm culture by modified photoactivated disinfection. Int Endod J 2013; 46(7): 649-659.

104:Yao N, Zhang C, Chu C. Effectiveness of photoactivated disinfection (PAD) to kill Enterococcus faecalis in planktonic solution and in an infected tooth model. Photomed Laser Surg 2012; 30(12): 699-704.

105:Jurič IV, Plečko V, Panduríc DG, Aníc I. The antimicrobial effectiveness of photodynamic therapy used as an addition to the conventional endodontic re-treatment: A clinical study. Photodiagnosis Photodyn Ther 2014; 11(4): 549555.

106:Souza LC, Brito PRR, Machado de Oliveira JC, Alves FRF, Moreira EJL, Sampaio-Filho HR, et al. Photodynamic therapy with two different photosensitizers as a supplement to Instrumentation/ irrigation procedures in promoting intracanal reduction of Enterococcus faecalis. J Endod 2010; 36(2): 292-296.

107:Muhammad OH, Chevalier M, Rocca JP, BrulatBouchard N, Medioni E. Photodynamic therapy versus ultrasonic irrigation: interaction with endodontic microbial biofilm, an ex vivo study. Photodiagnosis Photodyn Ther 2014; 11(2): 171-181.

108:Poggio C, Arciola CR, Dagna A, Florindi F, Chiesa M, Saino E, et al. Photoactivated disinfection (PAD) in endodontics: an in vitro microbiological evaluation. Int J Artif Organs 2011; 34(9): 889-897.

109:Garcez AS, Nuñez SC, Hamblin MR, Ribeiro MS. Antimicrobial effects of photodynamic therapy on patients with necrotic pulps and periapical lesion. J Endod 2008; 34(2): 138-142.

110:Garcez AS, Nuñez SC, Hamblim MR, Suzuki H, Ribeiro MS. Photodynamic therapy associated with conventional endodontic treatment in patients with antibiotic-resistant microflora: A preliminary report. J Endod 2010; 36(9): 1463-1466.

111:Yildirim C, Karaarslan ES, Ozsevik S, Zer Y, Sari T, Usumez A. Antimicrobial efficiency of photodynamic therapy with different irradiation durations. Eur J Dent 2013; 7(4): 469-473.

112:Bonsor SJ, Nichol R, Reid TM, Pearson GJ. Microbiological evaluation of photo-activated disinfection in endodontics (An in vivo study). Br Dent J 2006; 200(6): 337-341.

113:Schlafer S, Vaeth M, Hørsted-Bindslev P, Frandsen EVG. Endodontic photoactivated disinfection using a conventional light source: an in vitro and ex vivo study. Oral Surg Oral Med Oral Pathol Oral Radiol Endod 2010; 109(4): 634-641.

114:Sabino CP, Garcez AS, Núñez SC, Ribeiro MS, Hamblin MR. Real-time evaluation of two light delivery systems for photodynamic disinfection of Candida albicans biofilm in curved root canals. Lasers Med Sci 2015; 30(6): 1657-1665.

115:Zakariasen KL, Dederich DN, Tulip J, DeCoste S, Jensen SE, Pickard MA. Bactericidal action of carbon dioxide laser radiation in experimental dental root canals. Can J Microbiol 1986; 32(12): 942-946.

116:Önal B, Ertl T, Siebert G, Müller G. Preliminary report on the application of pulsed $\mathrm{CO}_{2}$ laser radiation on root canals with $\mathrm{AgCl}$ fibers: A scanning and transmission electron microscopic study. J Endod 1993; 19(6): 272-276.

117:Horiba N, Itoh A, Yamaguchi M, Matsumoto T, Senda A, Nakamura H. Effects of intracanal carbon dioxide laser irradiation on cultured human fibroblasts. Oral Surg Oral Med Oral Pathol Oral Radiol Endod 2005; 100(6): 767-771.

118:Kesler G, Koren R, Kesler A, Hay N, Gal R. Histological changes induced by $\mathrm{CO} 2$ laser microprobe specially designed for root canal sterilization: in vivo study. J Clin Laser Med Surg 1998; 16(5): 263-267.

119:Le Goff A, Dautel-Morazin A, Guigand M, Vulcain $\mathrm{JM}$, Bonnaure-Mallet $\mathrm{M}$. An evaluation of the $\mathrm{CO}_{2}$ laser for endodontic disinfection. J Endod 1999; 25(2): 105-108.

120:Meire M, Poelman D, De Moor R. Optical properties of root canal irrigants in the 300-3,000-nm wavelength region. Lasers Med Sci 2014; 29(5): 1557-1562. 